\title{
A comparative study of physical and chemical properties of different pozzolanic materials used for roller compacted concrete RCC dams
}

\author{
Abdallah I. Husein Malkawi ${ }^{1}{ }^{*}$, Ehab Shatnawi ${ }^{2}$, and Dima A. Husein Malkawi ${ }^{3}$ \\ ${ }^{1}$ Prof. and Chancellor, Fahad Bin Sultan University, Kingdom of Saudi Arabia \\ On Leave from Jordan University of Science and Technology, Irbid-Jordan \\ ${ }^{2}$ Project Geotechnical Engineer, CH2M,VA 20171, USA \\ ${ }^{3}$ Master Student, Civil Engineering Department, The University of Akron, Akron, OH, USA
}

\begin{abstract}
This paper addresses the feasibility and the efficiency of using Natural Pozzolan and/or Rock flour in Roller Compacted Concrete (RCC) gravity dams. For this purpose, five identical mortar trial mixes were prepared using five different supplementary materials, i.e., fly ash produced in South Africa (proven to be effective in RCC construction), fly ash produced in Turkey, Jordanian natural pozzolan, Saudi natural pozzolan, and rock flour from Mujib Dam basalt quarry. The physical and chemical properties of these pozzolanic materials were determined. The effectiveness of each one of these mineral admixtures used as a cement replacement material in controlling alkali silica reaction are studied and analyzed. Correlations were made between the mechanical properties for the five proposed mixes and a control mix using the Jordanian Portland Cement. The results demonstrate that the performance of Natural Pozzolana and/or rock flour as compared with that of fly ash and other pozzolanic material is very satisfactory and can be effectively used in RCC construction.
\end{abstract}

\section{Introduction}

Roller-compacted concrete (RCC) is defined as "concrete compacted by rolling compaction which, in its unhardened state, will support a roller while being compacted" (American Concrete Institute ACI). RCC dams consist of concrete placed at a lower water-to-cement ratio as compared to conventional concrete with the aid of compaction equipment and methodologies normally employed for earth-fill placement. RCC has gained worldwide acceptance as an alternative to conventional concrete in dam construction due to the construction advantages and proved performance [1]. According to Dunstan (2002) RCC dams continue their development worldwide and by the end of (2001) there were (232) complete large RCC dams and a further 31 were under construction, by the end of 2011 over 500 large RCC dams were developed in the world [2]. Recently there are more than 550 RCC dams in the world and approximately $45 \%$ are located in Asia. "During the meeting entitled

\footnotetext{
* Corresponding author: mhusein@just.edu.jo
} 
The Practicalities and Economics of RCC by Malcolm Dunstan, held at the British Dams Society in London on 20 January 2014". Forbes, et al. (1999, 2001) and Forbes $(2008$ and 2012) in his authoritative papers stated clearly that more significant innovations, improvement, efficient construction and at less cost have taken place since the first development of RCC dams in early 1990's [3,4,5,6]. Factors that affect the material properties of RCC are the same as those that affect the properties of conventional concrete, which are water-to-cement ratio, quality of grading in mixing, and degree of compaction and curing. The objective of RCC proportioning is to provide a dense and stable mass that meets the strength, durability, and permeability requirements for its application. Materials used for RCC include cementitious materials (Portland cement and pozzolans such as fly ash), aggregates, water, and admixtures. A wide range of materials have been used successfully to produce RCC mixtures. It is common practice in proportioning concrete mixtures for dams to utilize large aggregates in order to decrease cementitious material requirements and lower the costs and heat of hydration. RCC can be made with any of the basic types of cement or combination of cement and pozzolanic material. Selection of cementitious materials to resist the chemical attack of sulfate and potential alkali reactivity with certain aggregates should follow the same standard procedures adopted for CVC. The compressive strength of concrete is less dependent on the aggregate bond than tensile strength. Thus, it is apparent that the relationship between the tensile strength and compressive strength of concrete not only varies with the method of test, but also varies with the type and maximum size of aggregate. The strength of RCC is primarily dependent upon, the quality of the aggregate, degree of compaction, properties of cement, pozzolanic material, water, and admixtures if used, and grading of aggregate. Alkali aggregate reaction, as defined in the ACI Committee (1988), is a chemical reaction in mortar or concrete between alkalis (sodium and potassium) from Portland cement or other sources and certain constituents of some aggregates; under certain conditions, deleterious expansion of the concrete or mortar may result. Classic research by [7] correctly diagnosed the failure as being due to expansions caused by a chemical reaction between the alkalis contained in the cement paste and certain reactive forms of silica within the aggregate. Stanton found opal and chert to be common forms of reactive silica. [8] addressed the possibility and the efficiency of using Jordanian natural pozzolana in RCC gravity dams. For this purpose, two identical trial mix properties were proposed and undertaken using two different supplementary cementitious materials, i.e., fly ash brought from South Africa and Jordanian natural pozzolana. The study showed that Jordanian natural pozzolana produced satisfactory results. [9] studied the potential of alkali aggregate reaction of different types of Jordanian aggregate. The results indicate that the main types of Jordanian aggregates could be considered as innocuous aggregates, with no expected expansion resulting from alkali aggregate reaction, except some types of minerals such as opal and some types of sands and cherts. [10] states that all good RCC has a paste content of about $19 \%$ to $21 \%$ by volume, regardless of the cement and pozzolan or fly ash content. The paste includes "all material finer than 75 microns - cement, slag, pozzolan (fly ash), aggregate fines, admixtures, water, and air". Mixes with less paste are harsh and tend to segregate, whereas mixes with excess paste tend to produce less strength per kilogram of cementation material. Therefore, low cementitious content RCC requires aggregate fines in order to provide adequate paste without excessive water, and high cementitious content mixes require cleaner aggregates.

\section{Objectives}

The main objective of this study is to address the feasibility and the efficiency of using natural pozzolan and/or basalt rock flour in roller compacted (RCC) gravity dams. To achieve this, five different supplementary cementitious materials were used in preparing the mortar 
sample mixes, these are, fly ash produced in South Africa (proven to be effective in RCC construction), fly ash produced in Turkey, Jordanian natural pozzolan, Saudi natural pozzolan, and rock flour from Mujib Dam basalt quarry. The physical and chemical properties for each one of these cementitious materials will be determined. The effectiveness of each one of these mineral admixtures used as a cement replacement material in controlling alkali silica reaction are to be studied and analyzed. Correlations will be made between the mechanical properties for the five proposed mixes and the control mix using Jordanian Portland Cement.

\section{Materials properties}

\subsection{Pozzolanic materials}

The selection of pozzolanic material suitable for RCC should be based on its conformance with applicable standards (ASTM C-618). This standard defines pozzolan as "siliceous or siliceous and aluminous materials which in themselves possess little or no cementitious value but will, in finely divided form in the presence of moisture, chemically react with calcium hydroxide at ordinary temperatures to form compounds possessing cementitious properties". The type of pozzolanic material can include natural pozzolans; diatomaceous earth; Industrial waste material as fly ash or silica fume. The use of a pozzolanic material in RCC serves some purposes such as partial replacement for cement to reduce heat generation, increase workability and compressive strength at great ages, if the material has high pozzolanic activity with cement, increase durability, and reduce the effects of Alkali Aggregate Reaction and to reduce cost and, as a mineral addition to the mixture, to provide fines to improve workability.

\subsection{South Africa fly ash}

Fly ash is a residue of the combustion of the finely ground coal used in electric power generation. The fly ash class F material was not available in local markets and an attempt was made to import enough quantities from South Africa in order to be used in RCC mixtures. The fly ash material was tested in South Africa by Ash Resources.

\subsection{Turkey fly ash}

Fly ash was imported from Isken Sugozu Power Plant, located in the South East of Turkey. Chemical analysis is shown in Table 1.

\subsection{Jordanian natural pozzolan}

The natural pozzolan, which is exposed in large deposits throughout north-eastern Jordan at Tel-Alremah is used in the RCC mixture. The pozzolana was extracted, crushed, grinded and tested by the Jordan cement factory.

\subsection{Saudi natural pozzolan}

The Saudi natural pozzolan is available in large deposit throughout the western part of the Kingdom of the Saudi Arabia, and in the outskirts of Al-Madinah. The pozzolan was brought, 
crushed, grinded by the Pozzolan Product Factory (Burkani) located in the Jeddah Industrial Area. Table 1 shows the chemical analysis of the Saudi natural pozzolan.

\subsection{Basalt rock flour}

The rock flour used in this study was crushed basalt rocks came from a basalt quarry, located on the south rim of Wadi Mujib in the southern part of Jordan.

\subsection{Portland cement}

Portland cement Type II (low heat) was used in these mixes. The cement is manufactured by the Jordan Cement Factory. The chemical properties of the cement were periodically tested by the Royal Scientific Society Laboratories and the Department of Quality Control.

Table 1. Chemical analysis for the pozzolanic material.

\begin{tabular}{|c|c|c|c|c|c|}
\hline Determinant & \begin{tabular}{|l|} 
South \\
Africa \\
fly ash
\end{tabular} & $\begin{array}{l}\text { Turkey } \\
\text { fly Ash }\end{array}$ & $\begin{array}{c}\text { Jordanian } \\
\text { pozzolan }\end{array}$ & $\begin{array}{c}\text { Saudi } \\
\text { pozzolan }\end{array}$ & $\begin{array}{l}\text { Rock } \\
\text { Flour }\end{array}$ \\
\hline Free Water (\%) & 0.1 & 0.0 & 0.1 & 0.1 & 0.1 \\
\hline R_density $\left(\mathrm{g} / \mathrm{cm}^{3}\right)$ & 2.20 & 2.10 & 2.86 & 2.8 & 2.85 \\
\hline LOI (\%) & 0.81 & 1.10 & 2.56 & 1.26 & 2.31 \\
\hline Water Reqr. (\%) & 90 & 102 & 100 & 100 & 105 \\
\hline Blain & 2380 & 3670 & 4610 & 3200 & 5870 \\
\hline $\mathrm{SO}_{3}(\%)$ & 0.42 & 0.82 & 0.35 & 0.1 & - \\
\hline $\mathrm{CaO}(\%)$ & 4.18 & 3.02 & 9.75 & 8.53 & 11.02 \\
\hline $\mathrm{SiO}_{2}(\%)$ & 51.06 & 56.54 & 42.56 & 48.44 & 49.25 \\
\hline $\mathrm{Al}_{2} \mathrm{O}_{3}(\%)$ & 32.23 & 18.68 & 13.55 & 15.97 & 13.36 \\
\hline $\mathrm{Fe}_{2} \mathrm{O}_{3}(\%)$ & 3.42 & 10.83 & 13.24 & 13.2 & 11.3 \\
\hline $\operatorname{MgO}(\%)$ & 1.06 & 4.45 & 11.15 & 7.89 & 8.76 \\
\hline $\mathrm{TiO}_{2}(\%)$ & 1.70 & 0.83 & 2.54 & - & 1.57 \\
\hline $\mathrm{K}_{2} \mathrm{O}(\%)$ & 0.58 & 1.46 & 1.17 & 1.37 & 0.51 \\
\hline $\mathrm{Mn}_{2} \mathrm{O}_{3}(\%)$ & 0.01 & 0.16 & 0.14 & - & 0.190 \\
\hline $\mathrm{Na}_{2} \mathrm{O}(\%)$ & - & - & - & - & 0.51 \\
\hline
\end{tabular}

\subsection{Aggregates}

The selection of a suitable aggregate depends on a number of factors, including local availability, economics, size of the project, strength and durability requirements, and workability. The selected aggregates were crushed basalt which came from a basalt quarry, located high above the left abutment to Wadi al-Mujib, in Southern part of Jordan.

The Cilas Granulometre 715 device was used to determine the grain size distribution of the four cementitious materials used in this study. Tables $1 \& 2$ show the physical and chemical analysis for the five types of pozzolanic materials and the Jordanian OPC. Also, Figure 1 shows the grain size distribution of the five selected cementitious materials.

Table 2. Chemical analysis for the Portland cement.

\begin{tabular}{|c|c|}
\hline Item & Result (\%) \\
\hline $\mathrm{SiO}_{2}$ & 19.92 \\
\hline $\mathrm{Al}_{2} \mathrm{O}_{3}$ & 5.00 \\
\hline
\end{tabular}




\begin{tabular}{|c|c|}
\hline $\mathrm{Fe}_{2} \mathrm{O}_{3}$ & 3.31 \\
\hline $\mathrm{CaO}$ & 63.54 \\
\hline $\mathrm{MgO}$ & 3.36 \\
\hline $\mathrm{SO}_{3}$ & 3.05 \\
\hline $\mathrm{Na}_{2} \mathrm{O}$ & 0.19 \\
\hline $\mathrm{K}_{2} \mathrm{O}$ & 0.53 \\
\hline L.O.I & 1.49 \\
\hline
\end{tabular}

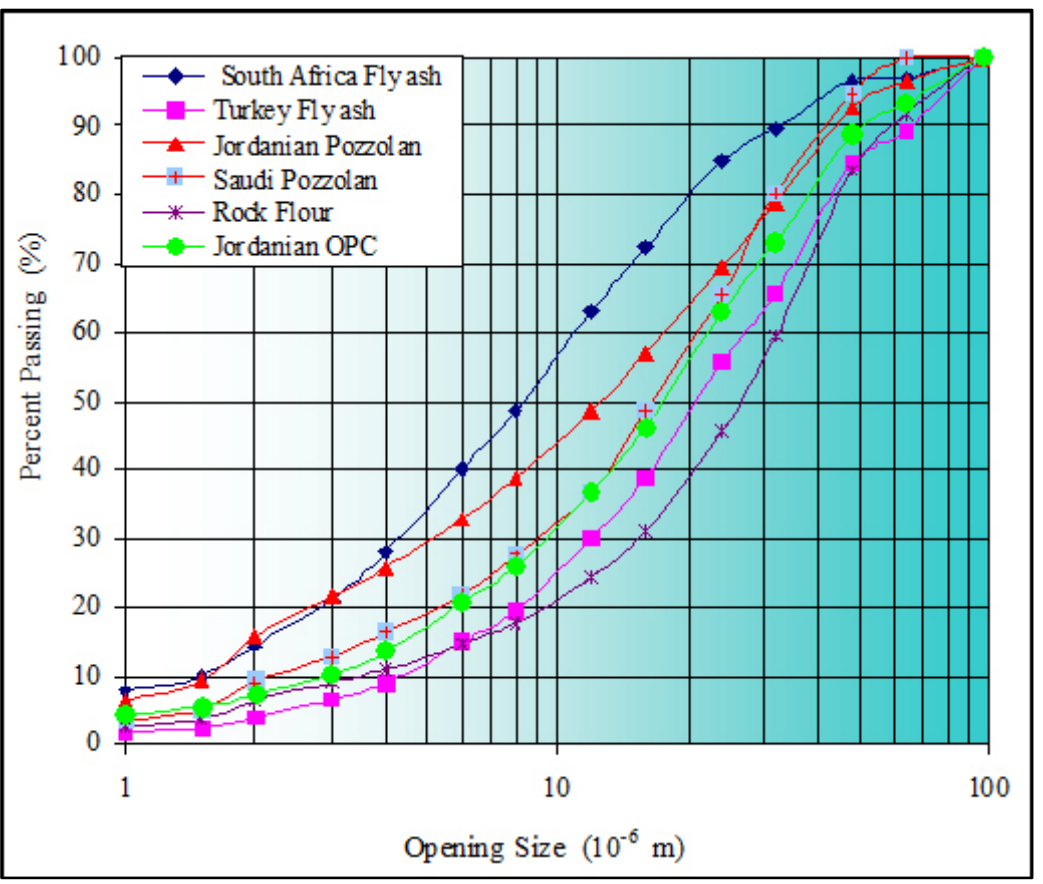

Fig. 1. Grain Size Distribution.

\section{Laboratory work}

\subsection{Compressive strength}

This investigation was carried out under laboratory conditions using procedures as described in ASTM C 109. The materials include (a) ordinary cement with class of strength $42.5 \mathrm{MPa}$ produces at Jordanian Cement Factory. (b) South Africa fly ash, Turkey fly ash, Jordanian pozzolana, Saudi natural pozzolan and basalt rock flour and basalt aggregate crushed to sand size. The test specimens from a control mixture and from a test mixture were molded in accordance with ASTM Test Method C 109/C 109M. In the test mixture, six percent with 10, $15,20,25,30$, and $40 \%$ of the mass of the cement used in the control mixture were replaced by the same mass of mineral admixture. The following weights were used to prepare the $(50 \mathrm{~mm})$ cubic samples:

1- Control Mixtures:

$500 \mathrm{~g}$ of Portland cement

$1375 \mathrm{~g}$ of graded standard sand (graded as ASTM C 778). 
$242 \mathrm{ml}$ of water

\section{2- Test Mixtures:}

450, 425, 400, 350, and $300 \mathrm{~g}$ of Portland cement.

$50,75,100,150$, and $200 \mathrm{~g}$ of mineral admixtures.

$1375 \mathrm{~g}$ of graded standard sand

$242 \mathrm{ml}$ of water.

The graded sand used was the basalt aggregate that was crushed to the sizes and amounts shown below:

Table 3. Seive analysis.

\begin{tabular}{|c|c|}
\hline Sieve & Amount used,\% \\
\hline No. 16 - No. 30 & 5 \\
\hline No. 30 - No. 40 & 30 \\
\hline No. 40 - No. 50 & 42 \\
\hline No. 50 - No. 100 & 23 \\
\hline
\end{tabular}

After the aggregate was separated into the various sieve sizes, each size was washed with water over the sieve to remove adhering dust and fine particles from the aggregate. The portions retained on the various sieves were dried and stored individually in a clean container. The dry materials for the test mortar were prepared using 1 part of cement to 2.75 parts of graded aggregate by mass to cast $50 \times 50 \times 50 \mathrm{~mm}$ cubes. Water to cement ratio equal to 0.485 by mass was used. After the mix proportions were prepared, the specimens were mechanically mixed in accordance with the procedure given in ASTM C 305. The specimens were molded immediately after the mixing of the mortar batch was finished, placing and tamping as required by ASTM C 109. Immediately upon completion of molding, the test specimens were placed in the moist room at $23.0 \pm 2.0^{\circ} \mathrm{C}$ for $24 \mathrm{~h}$, then the cubes were removed from the moist room and stored in storage water tanks as specified in test method C 109/C 109M. The compressive strength was determined, as specified in Test Method C $109 / \mathrm{C} 109 \mathrm{M}$, of two specimens of the control mixture and two specimens of the test mixture at ages of 7, 28, 90, 180, and 360 days.

\subsection{Alkali silica reactions}

This investigation was carried out under laboratory conditions using procedures as described in ASTM C 1260. The materials include ordinary OPC cement with class strength of 42.5 MPa produced at JCF, mineral admixtures of South Africa fly ash, Turkey flyash, Jordanian natural pozzolan, Saudi natural pozzolan, and rock flour, and aggregate composed of basalt aggregate crushed to sand size.

\subsection{Strength activity index with portland cement}

Tests specimens from a control mixture and from a test mixture were molded in accordance with Test Method C 109/C 109M. In the test mixture, $20 \%$ of the mass of the amount of cement used in the control mixture was replaced by the same mass of the test sample. ASTM C-311 suggested that six-cube batches to be made as follows:

1- Control Mixtures:

$500 \mathrm{~g}$ of Portland cement

$1375 \mathrm{~g}$ of graded standard sand (Ottawa sand, ASTM C 778).

$242 \mathrm{ml}$ of water

2- Test Mixtures:

$400 \mathrm{~g}$ of Portland cement. 
$100 \mathrm{~g}$ of test sample.

$1375 \mathrm{~g}$ of graded standard sand

$242 \mathrm{ml}$ of water

Although Specification C 618 specifies that "meeting the 7 day or 28 day Strength Activity Index will indicate specification compliance", 4 cubes of each batch were used for 7 and 28 day testing. After molding, the specimens were placed in the moist room at $23.0 \pm 2.0^{\circ} \mathrm{C}$ for $24 \mathrm{~h}$, then the cubes were removed from the moist room and stored the in saturated lime water as specified in Test Method C 109/C 109M. The compressive strength was determined, as specified in Test Method C 109/C 109M, of two specimens of the control mixture and two specimens of the test mixture at ages of 7 days, 28 days, 90 days and 180 days (see Figs 2$5)$.

\subsection{Heat of hydration}

The heat of hydration is the quantity of heat, in joules per gram of dehydrated cement, developed upon complete hydration at a given temperature. The most common method of determining the heat of hydration is by measuring the heat of the solution of dehydrated and hydrated cement in a mixture of nitric and hydrofluoric acids, the differences between the two values represent the heat of hydration. This method is described in BS 4550: Part 3: Section 3.8: 1978, and ASTM Standard C 186-78.

\section{Test results and discussion}

\subsection{Compressive strength}

Detailed data summarize the results of the average compressive strength at age 7,28, 90 and 180 days are shown in Figures 2 to Figure 5. It can be seen that the average peek compressive strength of RCC increases from $6 \mathrm{MPa}$ to more than $12 \mathrm{MPa}$ at the age of 180 days.

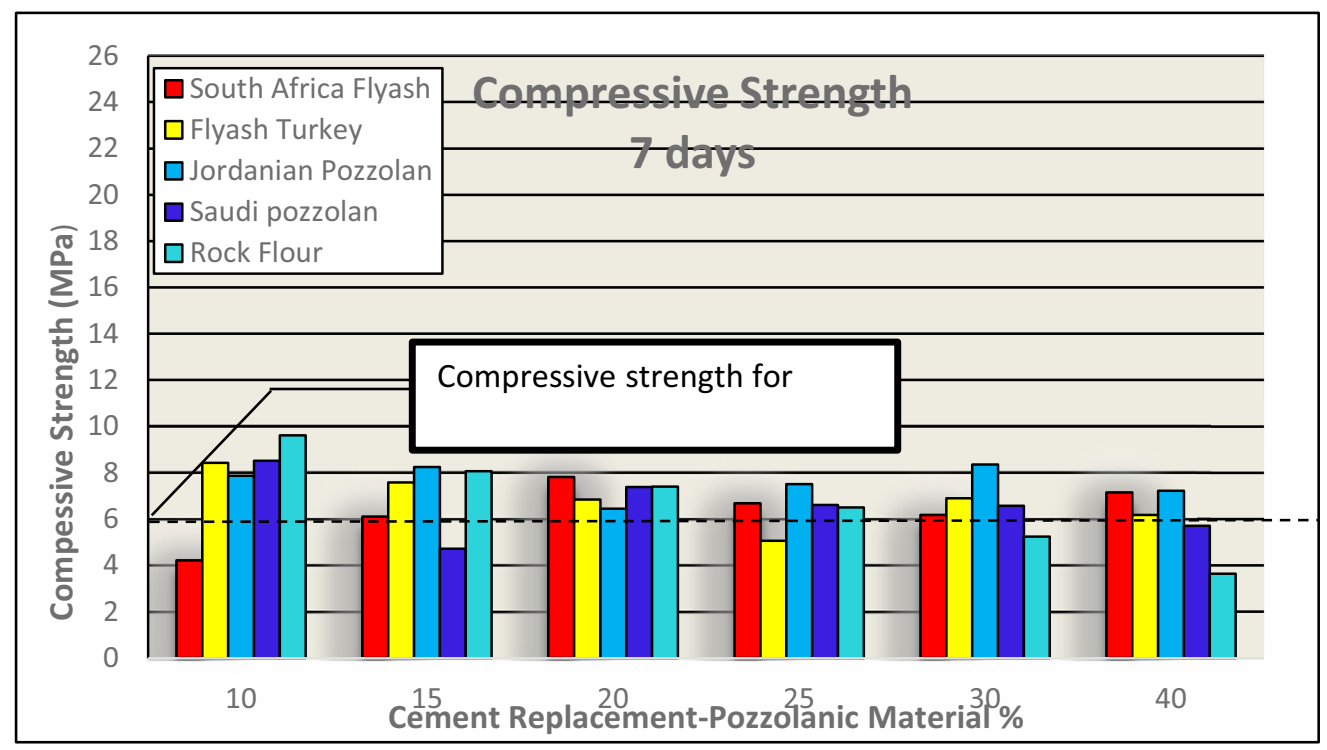

Fig. 1. Compressive Strength with Different Percent of Pozzolanic at 7 days. 


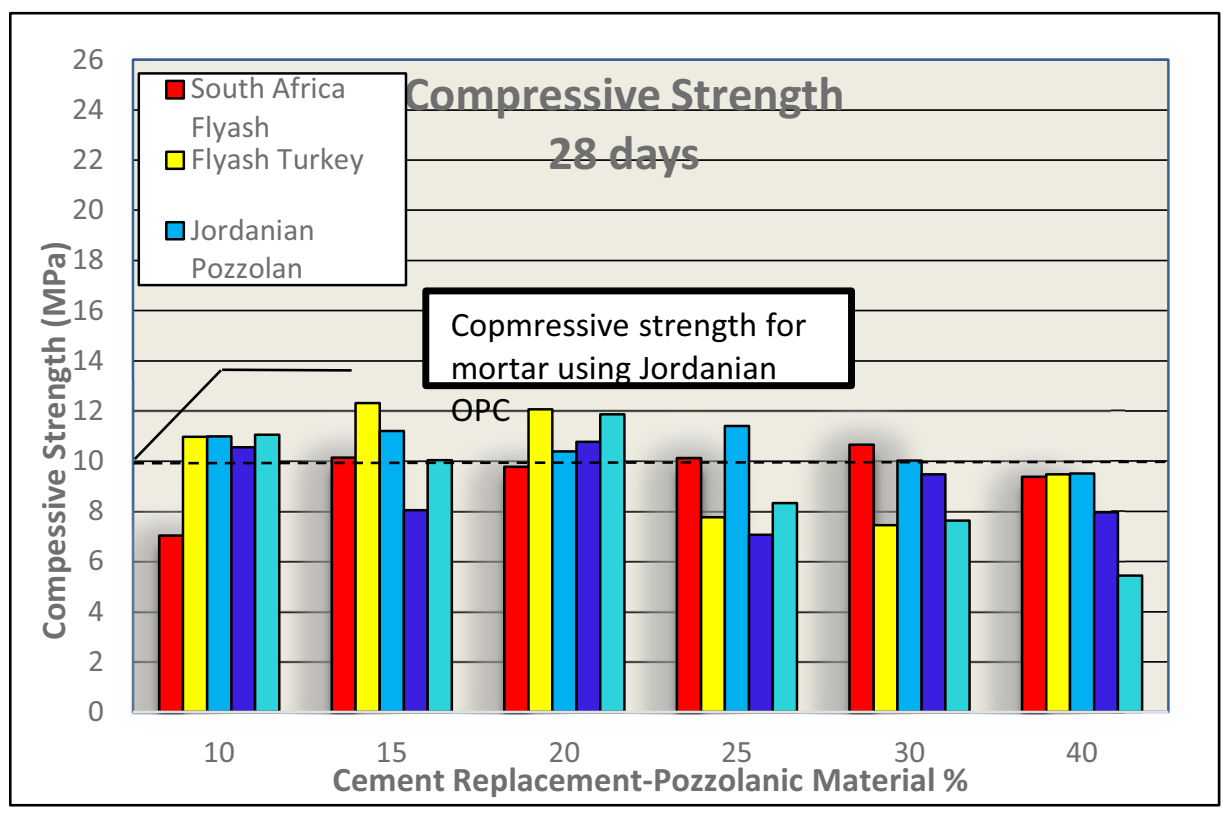

Fig. 2. Compressive Strength with Different Percent of Pozzolanic Materials at 28 days.

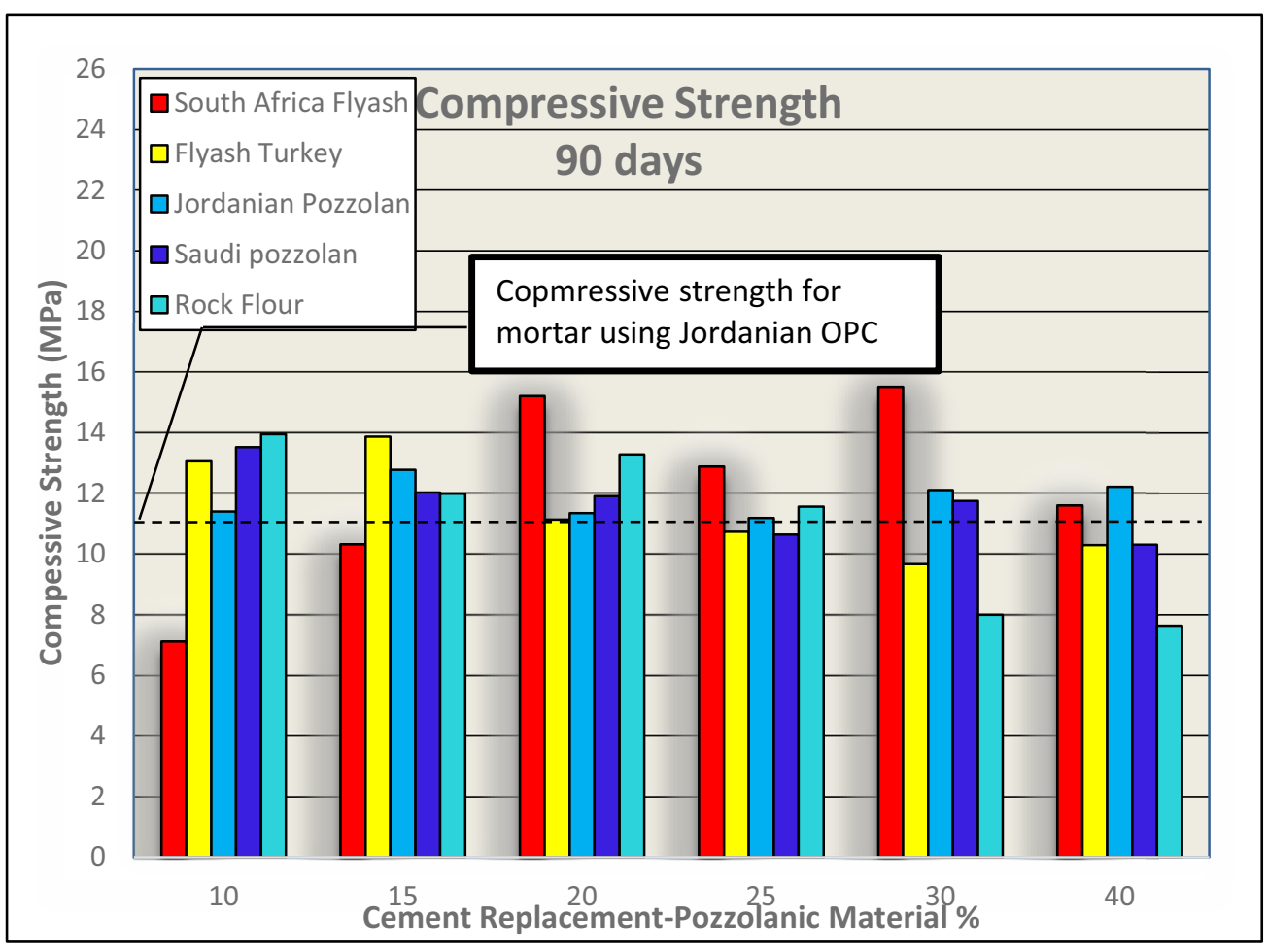

Fig. 4. Compressive Strength with Different Percent of Pozzolanic Materials at 90 days. 


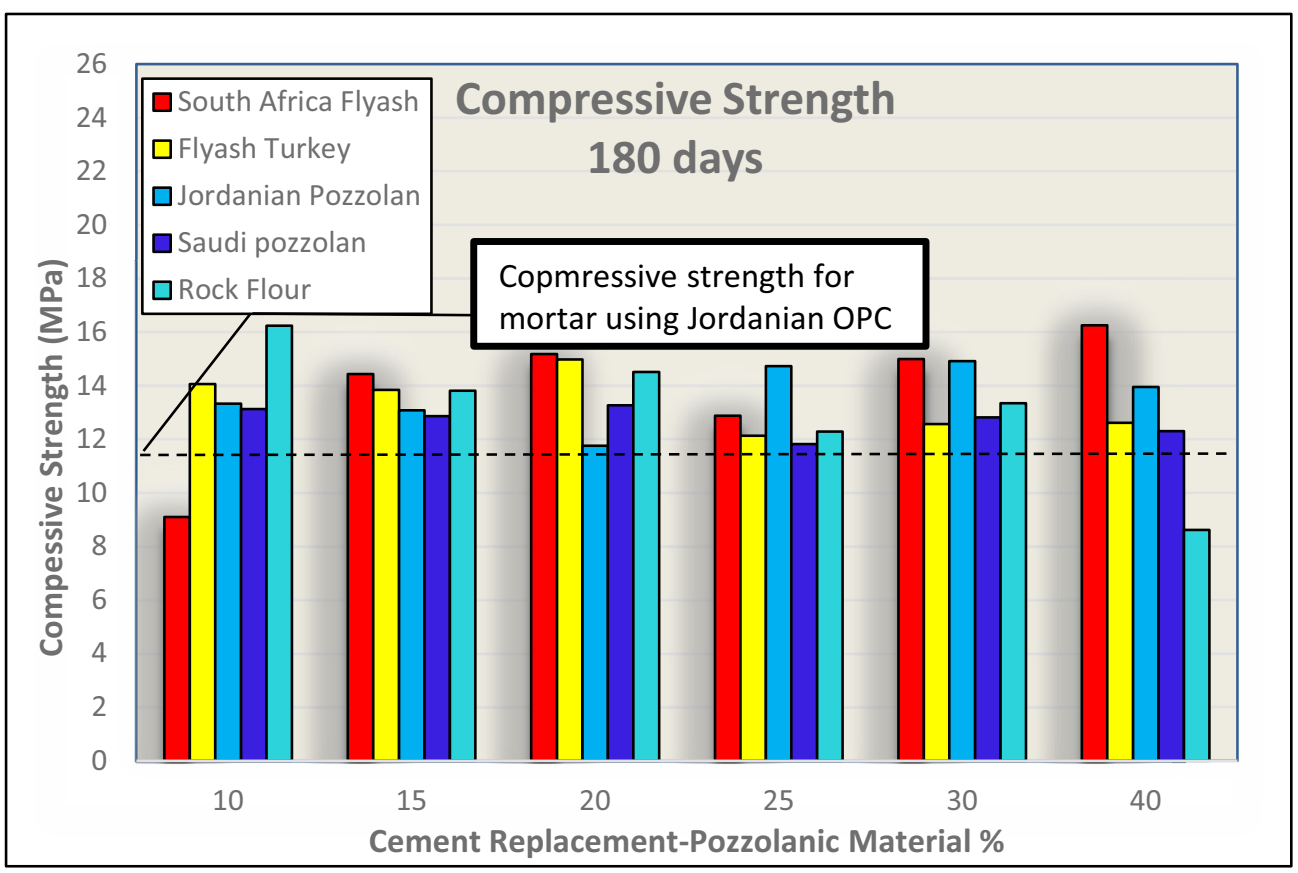

Fig. 5. Compressive Strength with Different Percent of Pozzolanic Materials at 180 days.

\subsection{Activity Index}

The pozzolanic activity index is calculated as follow:

Strength activity index with Portland cement $=(\mathrm{A} / \mathrm{B}) \times 100$

Where:

$A=$ average compressive strength of test mixture cubes.

$\mathrm{B}=$ average compressive strength of control mix cubes.

The activity index for the different tested pozzolanic materials, is shown in Figure 6 


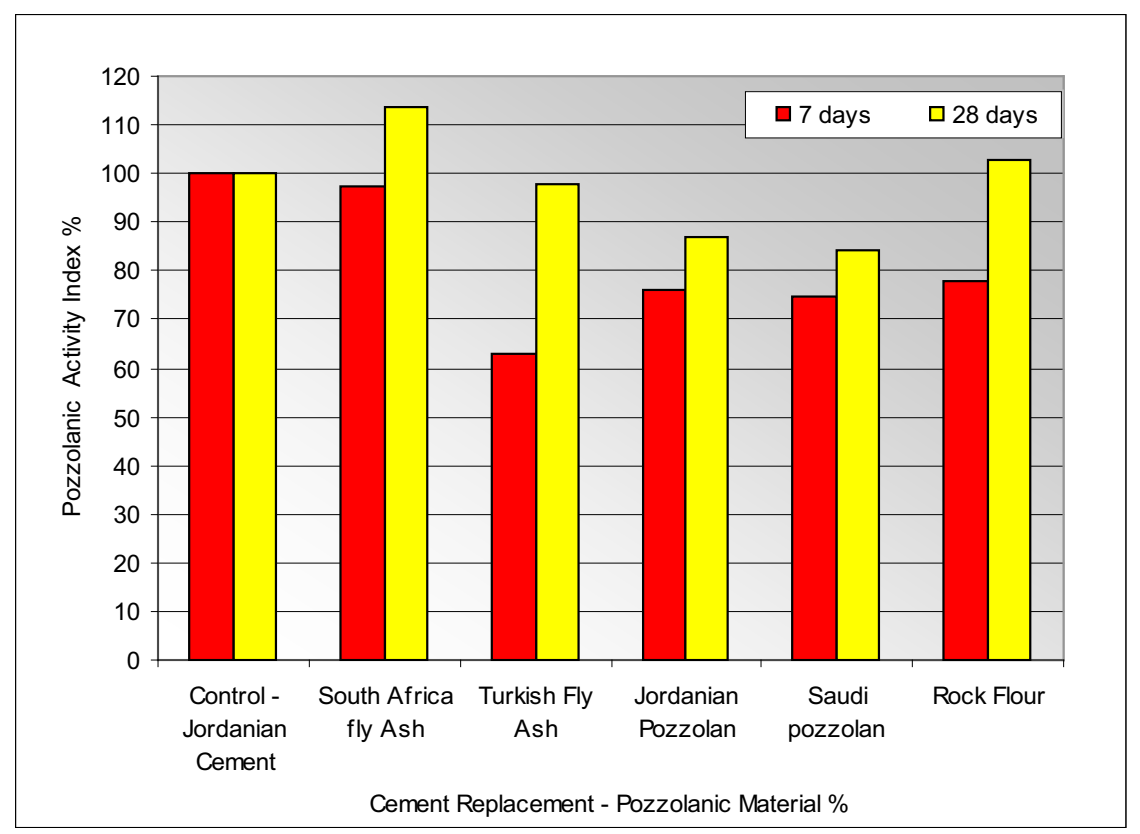

Fig. 6. Strength Activity Index with Portland cement

\subsection{Alkali silica reaction}

A 14-day expansion greater than $0.20 \%$ indicated a potentially reactive aggregate in the field, while a 14-day expansion smaller than $0.10 \%$ indicated a non-reactive (innocuous) aggregate. Recent specifications have mentioned that 14-day expansions higher than $0.10 \%$ should be used to classify aggregates as reactive. Figure 7, shows the test results for evaluating effectiveness of mineral admixture in controlling Alkali Silica Reactions.

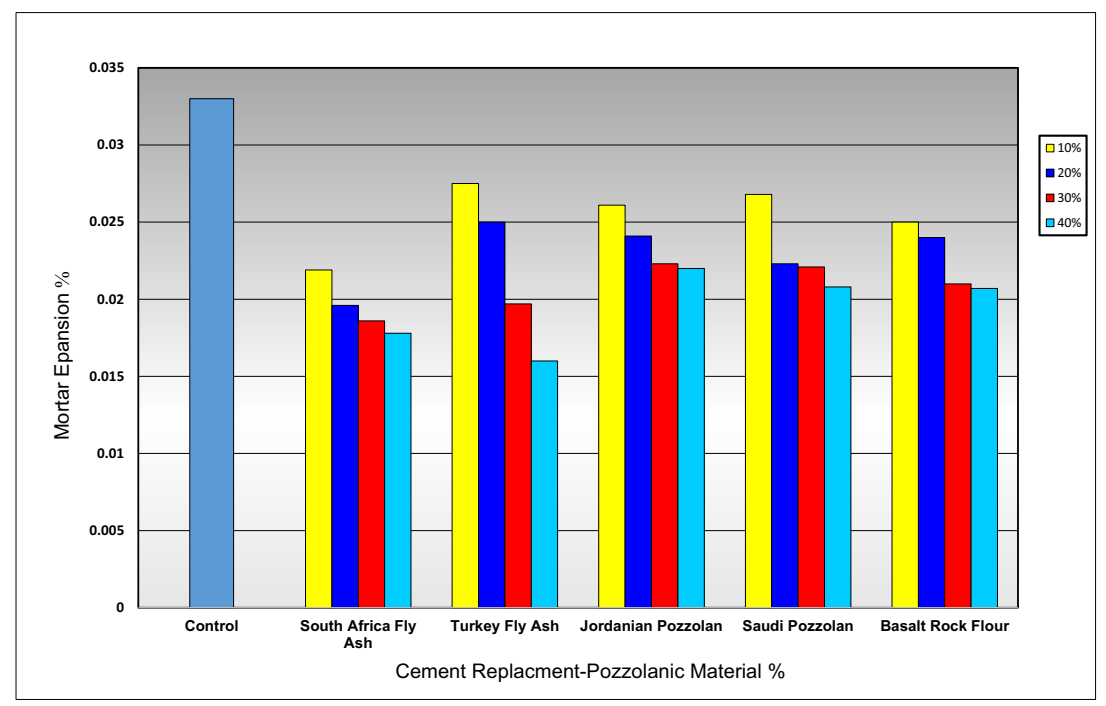

Fig. 7. 14-day expansions for mortar prepared by using different types of pozzolanic admixture 


\subsection{Heat of hydration}

Using the procedures listed above, the heat of hydration was calculated for the five different mixtures, that is the with fly ash from South Africa, fly ash from Turkey, Saudi natural pozzolan, Jordanian natural pozzolan and Rock flour. The results at age 7 days are shown in Figure 9, the heat of hydration for the zero percent of the pozzolanic material reflects the heat of hydration for Jordanian OPC cement.

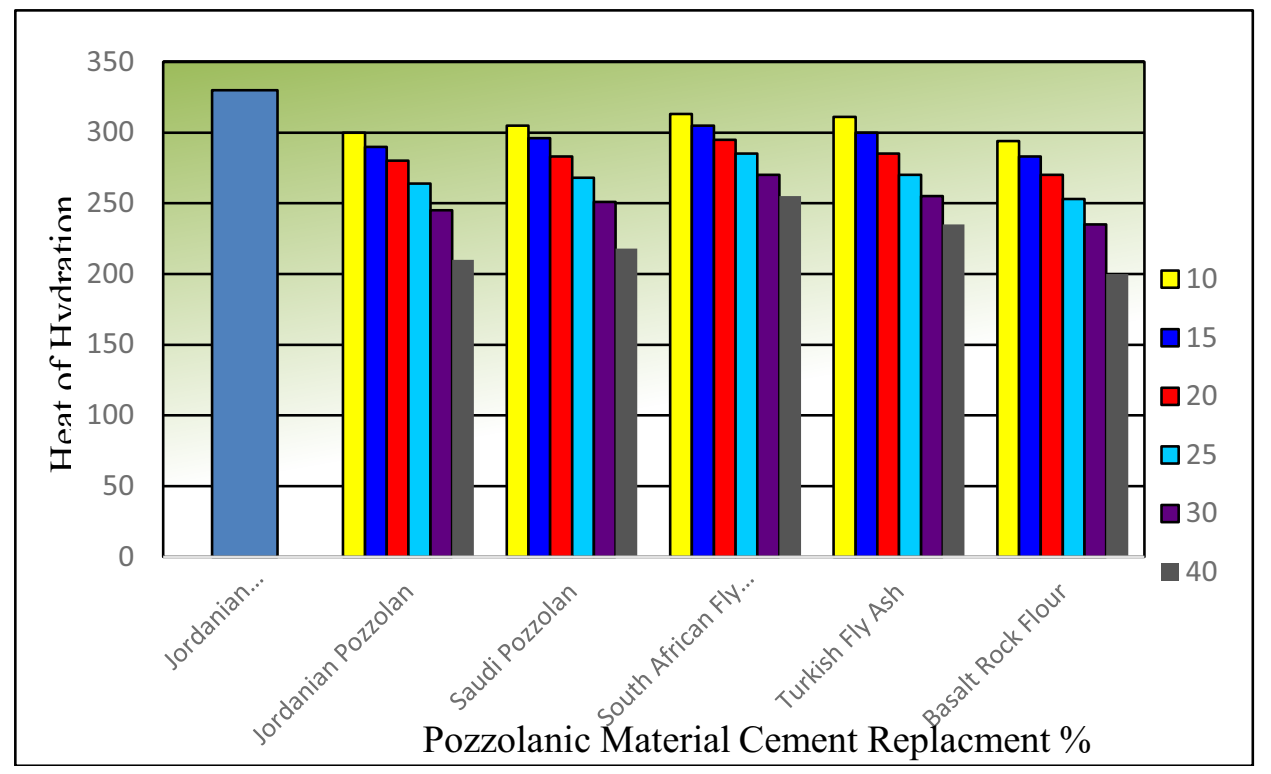

Fig. 8. The Accumulative Heat of Hydration after 7 days

\section{Conclusion}

Based on this study, the experimental and laboratory work performed in this investigation, indicate the following:

1. High strength of RCC mixtures used was obtained through specimens tests. It is clear that the contribution of fly ash and pozzolan can exhibit excellent strength of RCC especially over long time.

2. The results demonstrated that the performance of Natural Pozzolana as compared with that of fly ash and other pozzolanic material is very satisfactory and can be effectively used in RCC construction.

3. Natural pozzolana showed clearly its effectiveness in controlling alkali silica reaction

4. Using the pozzolanic materials in mixtures gives lower heat generation and water requirements that are improved workability in RCC mixtures used. This can be accomplished at cost savings despite higher cost of fly ash due to the water reduction and additional pozzolanic strength contribution of the ash.

5. Basaltic fines of about $20 \%$ replacement seems to be ideal in terms of achieving long term compressive strength, and less accumulative heat of hydration, compared to other cementitious materials. 


\section{References}

1. Luna R. and Wu Y. (2000) "Simulation of Temperature and Stress Field during RCC Dam Construction". Journal of Construction Engineering and Management, September/October.

2. The International Journal on Hydropower \& Dams - World Atlas, 2011.

3. Forbes, B. A. (2012) "Innovations of Significance and their Development on Some Recent RCC Dams" Invited Lecture, 6 ${ }^{\text {th }}$ International Symposium on Roller Compacted Concrete (RCC) Dams, Zaragoza, 23-25 October.

4. Forbes, B.A., Yang, L., Tang, G., and Yang, K. (1999) "Jiangya Dam China, Some Interesting Techniques Developed for High Quality RCC Construction". Proc. Of the International Symposium on Roller Compacted Concrete Dams. Chengdu, China, April.

5. Forbes, B.A. (2008) "RCC-New Developments and Innovations". Proc. Of the $50^{\text {th }}$ Brazilian Congress on Concrete-CBC2008, $1^{\text {st }}$ RCC Symposium. Salvador, Brazil, September.

6. Forbes, B.A., Iskander, M.M., and Husein Malkawi, A.I, (2001) "High RCC Standards Achieved at Jordan's Tannur Dam”. International Journal on Hydropower \& Dams, Issue Three.

7. Stanton, D. E. (1940) "Expansion of concrete through reaction between cement and aggregate". Proc. ASCE 66: 1781-1811.

8. Husein Malkawi, A.I.; Shaia, H.A.; Mutasher, S.A. and Aridah, M.F. (2003) "A Comparative Study of Mechanical Properties of RCC Trial Mix Using two Different Cementitious Materials (Fly Ash and Natural Pozzolan)". 4th International Symposium on Roller Compacted Concrete (RCC) Dams, 17-19 November, Spain.

9. Husein Malkawi, A.I.; Abed, A. and Rababa, S. (2003) "Behavior of the reaction between certain Jordanian rock-aggregate and cement in roller compacted concrete (RCC) dams". $4^{\text {th }}$ International Symposium on Roller Compacted Concrete (RCC) Dams, 17-19 November, Spain.

10. Schrader, E. (2002) "Experience and Lessons Learn in 30 Years of Design, Testing, Construction, and Performance of RCC Dams". In Husein Malkawi et al. (ed.), Roller Compacted Concrete Dam Construction in the Middle East; Proc. intern. Conf., Irbid-Jordan, 7-10 April 2002. Jordan University of Science and Technology \& Technische Universität München.

11. Dunstan, M.R. (2002) "The state of art of RCC dams at the end of 2001". In Husein Malkawi et al. (ed), Roller compacted concrete dam construction in Middle East; Proc. Int. Conf., Irbid- Jordan, 7-10 April 2002. Jordan University of Science and Technology \& Technische Universität München.

12. Hobbs, D.W. (1988) Alkali-silica reaction in concrete. London: Thomas Telford.

13. Lane, D.S and Ozyildirum, H. (1990) "Evaluation of the effect of Portland cement alkali content, fly ash, ground slag, and silica fume on alkali-silica reactivity". Cement, Concrete, and Aggregates Journal 21(2): 126-140.

14. Mantuani, D.L (1983). Handbook of concrete aggregates. New Jersy: Noyes Publications.

15. Thomas, M.D. \& Innis, F.A. 1998. Effect of slag on expansion due to alkaliaggregate reaction in concrete. ACI Materials Journal 95 (6): 716-721.

16. Wang, H. \& Gillott, J.E. (1993) "Effect of three natural Zeolite-containing Pozzolanic materials on alkali-silica reaction". Cement, Concrete, and Aggregates Journal 15: 24-44. 